\title{
AN UNDEMOCRATIC GUARDIAN OF DEMOCRACY - INTERNATIONAL HUMAN RIGHTS COMPLAINT PROCEDURES
}

\author{
Shotaro Hamamoto*
}

This paper discusses the individual complaints procedures established pursuant to international human rights treaties such as the International Covenant on Civil and Political Rights. It discusses the bases on which these systems have been criticised as undemocratic. After considering how these democratic failings could be ameliorated through greater involvement of domestic parliaments, it questions this narrow view of democracy that looks only to parliamentary involvement, suggesting instead that apparently undemocratic individual complaints procedures can actually have a beneficial "democratising" effect.

\section{INTRODUCTION}

The individual complaint procedures established by international human rights treaties ${ }^{1}$ have achieved remarkable success, as attested by the considerable number of cases brought before them. ${ }^{2}$ This quantitatively impressive level of success should not, however, distract attention from the

* Professor of International Law, Graduate School of Law, Kobe University, Japan.

1 International Convention on the Elimination of All Forms of Racial Discrimination (21 December 1965) 660 UNTS 195, art 14; Optional Protocol to the International Covenant on Civil and Political Rights (16 December 1966) 999 UNTS 302 [first Optional Protocol]; Convention against Torture and Other Cruel, Inhuman or Degrading Treatment or Punishment (10 December 1984) 1465 UNTS 85, art 22 [CAT]; Optional Protocol to the Convention on the Elimination of Discrimination against Women (10 December 1999) 2131 UNTS 83

2 UN Human Rights Committee "Report of the Human Rights Committee" (27 September 2005) A/60/40, vol I, para 106 ["HRC 2005 Report"]; Committee against Torture "Report of the Committee against Torture" (2005) A/60/44, para 136; "Report of the Committee on the Elimination of Discrimination against Women" (2005) A/60/38, paras 389-390. As for the Convention for the Elimination of Racial Discrimination (CERD), see the Treaty Body Database www.unhchr.ch/tbs/ (accessed 31 October 2006), as "Report of the Committee on the Elimination of Racial Discrimination" (2005) A/60/18, para 436 does not indicate the number of communications submitted. 
qualitative impact that it exerts on the internal legal order of the states parties to the system. Cooke P noted in Tavita $v$ Minister of Immigration that: ${ }^{3}$

since New Zealand's accession to the Optional Protocol, the United Nations Human Rights Committee is

in a sense part of this country's judicial structure, in that individuals subject to New Zealand jurisdiction

have direct rights of recourse to it.

Growth in the number and influence of international institutions is matched by increasingly fierce reactions from states. Traditionally, problems states face as a result of the development of international relations have been analysed in terms of sovereignty: numerous studies have examined the compatibility of international obligations and the very notion of sovereignty, ${ }^{4}$ the impact of the development of international organisations on State sovereignty, ${ }^{5}$ and, more recently, the meaning of sovereignty in the rapidly globalising world. ${ }^{6}$ However, the infiltration of international institutions into internal legal relations, as described by Cooke $\mathrm{P}$, invites reactions of a different nature from States.

Malcolm Fraser, former Prime Minister of Australia, wrote more than ten years ago that: ${ }^{7}$

Human rights are as well safeguarded in Australia as in any country I could name ... Yet we give UN committees concerned with human rights the capacity to review and to take action that can lead to the overturning of Australian law ... The Government is doing all this, of course, without telling the Australian people, without having asked their permission. It is not the Government's sovereignty that is being given away, it is the sovereignty that belongs to all Australians acting together ... Former Senator Peter Walsh ... wrote: 'I ... find it ironic that so many contemporary Australians, determined to protect us from the non-existent threat of English tyranny, fall over each other in a scramble to surrender Australian sovereignty to a rag-tag and bobtail of unrepresentative United Nations committees, accountable to nobody.'

States claim that not only sovereignty but democracy is being threatened by the development of supervisory organs established by international human rights treaties. Admittedly it seems that, prima facie, individual complaint procedures are destined to be tainted by a triple democratic illegitimacy: they are created by inter-state agreements, which often enter into force through an undemocratic procedure; supervisory organs established by such inter-state agreements are composed of members elected not by popular vote but by governments; and the organs so composed apply rules

3 Tavita v Minister of Immigration [1994] 2 NZLR 257, 266 Cooke P.

4 Wimbledon (Judgment) [1923] PCIJ (Series A, No 1) 25.

5 See generally Marc Stanislas Korowicz Organisations internationales et souveraineté des États membres (Pedone, Paris, 1961).

6 See generally Susan Strange The Retreat of the State (Cambridge University Press, Cambridge, 1996).

7 Malcolm Fraser "UN Poses Biggest Threat to Our Sovereignty" The Australian (18 August 1994) 13. 
and principles prescribed in human rights treaties, which may be amended only through an undemocratic procedure, even when peoples of states parties wish to reverse a decision or a decision of those organs. ${ }^{8}$

The question of the democratic (il)legitimacy of individual complaint procedures thus has much in common with the issue of the democratic legitimacy of international organisations on the international plane ${ }^{9}$ and of the judiciary in the internal legal order. ${ }^{10}$ Certainly, as is the case with international organisations or domestic courts, supervisory organs established by human rights treaties may found their legitimacy on their expertise in the matters which fall within their competence (known as intellectual or elitist legitimacy): ${ }^{11}$ for example, the members of the Human Rights Committee (HRC) of the International Covenant on Civil and Political Rights (ICCPR) are supposed to be "persons of high moral character and recognized competence in the field of human rights". ${ }^{12}$ However, it is extremely difficult to consider them "representative" or "accountable to the people". Should we, then, try to "democratise" individual complaint procedures? Or, is it possible for undemocratic organs to play a role in promoting and strengthening democracy? This article examines these problems, placing a particular emphasis on the HRC of the ICCPR, the most "productive" universal supervisory organ, and the practice of Australia, Canada, Japan, New Zealand

8 See Louis Favoreu "Quel(s) modèle(s) constitutionnel(s)?" (1995) 7 Revue universelle des droits de l'homme 357,360 .

9 See, for example, Robert A Dahl "Is International Democracy Possible?" in Sergio Fabbrini (ed) Democracy and Federalism in the European Union and the United States (Routledge, London, 2005) 194; Eric Stein "International Integration and Democracy" (2001) 95 Am J Int'l L 489.

10 See, for example, Ross Sandler and David Schoenbrod Democracy by Decree (Yale University Press, New Haven, 2003); Séverine Brondel, Norbert Foulquier and Luc Heuschling (Sous la direction de) Gouvernement des juges et démocratie (Publications de la Sorbonne, Paris, 2001).

11 Yoïchi Higuchi "Le problème de la légitimité du juge international à la lumière de la comparaison avec le problème de la légitimité du juge constitutionnel national" in Yoïchi Higuchi Constitution, idée universelle, expressions diversifiées (Société de législation comparée, Paris, 2006) 97 (first published in Liber Amicorum Juge Shigeru Oda (Kluwer, The Hague, 2002)).

12 International Covenant on Civil and Political Rights (16 December 1966) 999 UNTS 171, art 28, para 2 [ICCPR]. 
and the United States in relation to the HRC. ${ }^{13}$ The European Court of Human Rights, the most advanced regional organ, will also be mentioned extensively. ${ }^{14}$

\section{DEMOCRATIC LEGITIMATION THROUGH PARLIAMENTARY INVOLVEMENT}

The democratic illegitimacy of individual complaint procedures may be said to stem from the lack of democratic control over the process of human rights norm-making and the election of supervisory organ members. If so, the most straightforward strategy to cope with the problem would be to strengthen democratic control over these processes. While this strategy is not entirely unrealistic, it risks getting caught in the trap of "majoritarian difficulty".

\section{A Extensive Involvement of Parliament}

\section{Treaty-making}

In a number of member states of the Commonwealth, treaties are negotiated and entered into by the executive without approval by parliament. Even though the executive is comprised of members of the majority in parliament under the cabinet system, the absence of parliament's participation in the treaty-making process makes the products, namely treaties, essentially undemocratic. There is, however, a notable recent trend in these states to introduce a sort of parliamentary scrutiny of treaty-making process. ${ }^{15}$ Even if a parliamentary scrutiny system does not give the parliament a veto power in the treaty-making process, as is the case in Australia ${ }^{16}$ or in New Zealand, ${ }^{17}$ treaties concluded through such a system will be vested with a higher degree of democratic legitimacy.

13 This article, however, makes less mention of Japan and of the United States, neither of which has accepted any individual complaint procedure. The justification advanced by the Japanese Government in this regard ("the independence of the judiciary": see Minister of Justice's reply Shugiin Homu Iinka Kaigiroku [Records of the Committee on Judicial Affairs, House of Representatives] (3 October 2003) 15) shall not be analysed here as it is related to the question of democratic legitimacy only in an indirect manner. The United States Government, for its part, does not explain why it does not accede, for example, to the First Optional Protocol. John Quigley "The International Covenant on Civil and Political Rights and the Supremacy Clause" (1993) 42 DePaul L Rev 1287, 1295.

14 Convention for the Protection of Human Rights and Fundamental Freedoms (4 November 1950) 005 ETS, as amended by Protocol No 11, 155 ETS [European Convention on Human Rights or ECHR]. The present paper does not deal with the American Convention on Human Rights (21 November 1969) 1144 UNTS 123, the African Charter on Human and Peoples' Rights (27 June 1981) 1520 UNTS 217, or the Protocol to the African Charter on Human and Peoples' Rights on the Establishment of an African Court on Human and Peoples' Rights (9 June 1998) OAU/LEG/EXP/AFCHPR/PROT (III).

15 See generally Joanna Harrington "Scrutiny and Approval" (2006) 55 ICLQ 121; Julia Yoo "Participation in the Making of Legislative Treaties" (2003) 41 Colum J Transnat'l L 455.

16 Rosalie Balkin "International and Domestic Law" in Sam Blay, Ryszard Piotrowicz and Martin Tsamenyi (eds) Public International Law (2 ed, Oxford University Press, Melbourne, 2005) 115, 124-125; Donald K 
In those states where parliamentary approval is required for the government to ratify or to accede to certain categories of treaties, ${ }^{18}$ the democratic legitimacy of the treaties falling into these categories is guaranteed. Practice in Japan generally requires the Diet's approval before human rights treaties are ratified, for example. ${ }^{19}$

\section{Election of members}

The fundamental basis of claims that the judiciary in the internal legal orders lacks democratic legitimacy is the fact that judges are not elected, ${ }^{20}$ and thus not accountable to the people. On the contrary, members of the supervisory organs established by human rights treaties are elected by states parties to the treaties. ${ }^{21}$

However, it is an exaggeration to say that this election procedure guarantees the democratic legitimacy of the supervisory organs. Even if the representatives of states parties are considered ultimately democratically accountable to the citizens they represent - an assumption that is not always valid - the process of nomination and voting takes place so far from those who are represented that they have to be satisfied with extremely little control, if any, over these state representatives. Indeed,

Anton, Penelope Mathew and Wayne Morgan International Law (Oxford University Press, Melbourne, 2005) 426-443.

17 See Geoffrey Palmer "Human Rights and the New Zealand Government's Treaty Obligations" (1999) 29 VUWLR 57, 61-62; Mai Chen "A Constitutional Revolution?" (2001) 19 NZULR 448; Treasa Dunworth "International Treaty Examination" (2002) NZ Law Rev 255.

18 For the United States, see American Law Institute Restatement of the Law Third, Foreign Relations Law of the United States (St Paul, Minnesota, 1987) §303. For Japan, see below n 19. As for Canada, Turp indicates that "la pratique [canadienne] en vertu de laquelle le gouvernement déposait [au Parlement] une copie des traités internationaux en vigueur pour le Canada est maintenant chose du passé" ("the Canadian practice in which the Government of the day deposited copies of international treaties in Parliament is now a thing of the past"): Daniel Turp "Un nouveau déficit démocratique" in The Impact of International Law on the Practice of Law in Canada: Proceedings of the 27th Annual Conference of the Canadian Council on International Law, Ottawa, October 15-17, 1998 (Kluwer, The Hague, 1999) 119. See also Joanna Harrington "Redressing the Democratic Deficit in Treaty Law Making" (2005) 50 McGill L J 465, 477-478; Gibran van Ert Using International Law in Canadian Courts (Kluwer, The Hague, 2002) 66-71.

19 For the categories of treaties which need to be approved by the Japan's Diet, see the statement of the Minister for Foreign Affairs made in 1974. Shigeru Oda and Hisashi Owada "Annual Review of Japanese Practice in International Law XVI (1974-75)" (1984) 27 Japanese Ann Int'l L 79, 104-105. See also Article 73 of the Japan's Constitution (English translation available at the Prime Minister's Website www.kantei.go.jp (accessed 31 October 2006)). The Diet of Japan approved the ratifications of the ICCPR (6 June 1979) and the CEDAW (24 June 1980) and the accessions to the CERD (1 December 1995) and the CAT (9 June 1999).

20 In the United States, however, many state judges are elected. Larry C Berkson, updated by Rachel Caufield "Judicial Selection in the United States" www.ajs.org (accessed 31 October 2006) 6.

21 ICCPR, above n 12, art 29; CERD, above n 2, art 8, para 2; CAT, above n 1, art 17, para 2; Convention on the Elimination of All Forms of Discrimination against Women (18 December 1979), 1249 UNTS 13, art 17, para 2 [CEDAW]. 
Japan's Diet has no say in the process of the nomination and election of the supervisory committee members: neither the nomination nor the election of the Japanese HRC member Nisuke Ando, first elected in 1986 and re-elected four times, has ever been mentioned in parliamentary records. ${ }^{22}$ The same applies to the nomination and election of Yuji Iwasawa, who was elected a member of the HRC in $2006 .^{23}$

To compensate for this democratic deficit in the process of the nomination and election of supervisory organ members, one might think of introducing a procedure similar to the one used to elect judges of the European Court of Human Rights. There, the judges are elected by the Parliamentary Assembly of the Council of Europe, ${ }^{24}$ which consists of representatives elected by parliaments of Member States. ${ }^{25}$ It is true that "la procédure d'élection des juges par l'Assemblée parlementaire du Conseil de l'Europe est sans doute la meilleure solution du point de vue de la légitimité de cette juridiction, de par son aspect éminemment démocratique." 26 Although the creation of a "parliamentary assembly" in the UN system almost belongs to a fairy-tale world, it would not be completely unrealistic to have states parties' parliaments involved somehow in the nomination or election process of the members of supervisory organs.

\section{B Majoritarian Difficulty}

The measures discussed in the preceding section, albeit as an extremely remote possibility, may enhance the democratic legitimacy of the individual complaint procedures established by human rights treaties. But will these measures contribute to the promotion and the protection of human rights, for which these procedures were created?

The democratisation of the treaty-making process by way of increasing parliamentary involvement may discourage countries from acceding to international human rights instruments. When the United States Government asked the Senate to consider the ratification of the ICCPR, it submitted a package that proposed special United States conditions of ratification, consisting of five reservations, five understandings and four declarations. ${ }^{27}$ Despite these extremely restrictive

22 Search in the database of the Japan's Diet records http://kokkai.ndl.go.jp (accessed 31 October 2006). See ICCPR, above n 12, art 29, para 2.

23 See Diet records, ibid.

24 European Convention on Human Rights, above n 14, art 22, para 1.

25 Statute of the Council of Europe (5 May 1949) 001 ETS, art 25, para 1.

26 "[T]he procedure for the election of judges to the Parliamentary Assembly of the Council of Europe is without doubt the best solution from the point of view of the procedure's outward democratic legitimcy." Marina Eudes "La légitimité du juge de la Cour européenne des droits de l'homme" (2000) 13 Revue québécoise de droit international 131,144

27 United States Senate "Senate Executive Report No 102-23" (102d Cong, 2d Sess) 6-9, reprinted in (1992) 31 ILM 648, 651-652. 
conditions, which led some commentators to examine whether the United States could be considered a party to the ICCPR at all, ${ }^{28}$ the Senate thought it necessary to subject its approval to the following additional proviso: "Nothing in this Covenant requires or authorizes legislation, or other action, by the United States of America prohibited by the Constitution of the United States as interpreted by the United States." 29 Given this defensive attitude of the Senate, it seems most unlikely that it will approve, in the foreseeable future, of participation in the individual complaint procedures under the First Optional Protocol. Such a procedure could entail the HRC finding certain United States legislation incompatible with obligations that the United States has assumed under the ICCPR.

This is not a position peculiar to the United States. As far as people consider their parliament as truly democratic, they will not wish to see their parliament's legislation amended or declared incompatible with international norms by non-representative organs such as a court or a supervisory organ established by an international human rights treaty. In fact, such a profound confidence in the democratic character of Parliament explains the unentrenched nature ${ }^{30}$ of the New Zealand Bill of Rights Act, ${ }^{31}$ which explicitly precludes judicial invalidation of inconsistent legislation in section 4. As a New Zealand representative stated to the HRC: ${ }^{32}$

the Government had initially proposed entrenchment of the Bill of Rights as supreme law but public reaction had been unfavourable. In general, New Zealand society was reluctant to accept the concept of entrenchment and, in that particular case, was wary of transferring power from elected representatives to non-elected judicial officers. Accordingly, on the basis of public hearings, the Parliament had decided that the Bill of Rights should be enacted as an ordinary statute which could be amended or superseded.

It is to be noted in this context that, while New Zealand is party to the first Optional Protocol to the ICCPR, no parliamentary approval was necessary for the New Zealand Government to ratify the Optional Protocol. ${ }^{33}$

Similarly, possible parliamentary involvement in the election process of the members of supervisory organs may end up by creating an individual complaint procedure unfriendly to human rights, ${ }^{34}$ and an excessively politicised election process. ${ }^{35}$

28 See, for example, William A Schabas "Invalid Reservations to the International Covenant on Civil and Political Rights" (1995) 21 Brooklyn J Int'l L 277, 316-323.

29 Senate (102d Cong 2d Sess) (2 April 1992) 138 Cong Rec S 4784.

30 Paul Rishworth and others The New Zealand Bill of Rights (Oxford University Press, Melbourne, 2003) 2.

31 New Zealand Bill of Rights Act 1990.

32 Mr Keating (New Zealand) (7 April 1995) CCPR/C/SR.1393, para 14.

33 See Palmer, above n 17.

34 A good example would be the fate of the three judges of the California Supreme Court, who, after making themselves unpopular with the electorate by consistently voting to reverse death sentences, lost in their 
Thus, the more democratically legitimate the individual complaint procedures become, the less protective of human rights. Does this conclusion mean that we had better stop seeking democratic legitimacy in individual complaint procedures? Or are we asking the wrong question?

\section{AN UNDEMOCRATIC ORGAN ENHANCING DEMOCRACY}

In the preceding section, we examined the democratic legitimacy of individual complaint procedures solely from the perspective of parliamentary involvement. There are at least two underlying assumptions in the analysis: democracy means majority rule; and, a majority in the parliament represents the will of a majority of the people, if not the volonté générale.

These assumptions can be called into doubt. It is well known that parliaments (or parliamentarians) do not always represent the will of a majority of the electorate: as Jean-Jacques Rousseau stated in as early as 1762, "[l] e peuple anglais pense être libre, il se trompe fort; il ne l'est que durant l'élection des membres du parlement: sitôt qu'ils sont élus, il est esclave, il n'est rien."36 More important, however, is the definition of democracy. The preceding section showed the inevitable conclusions we reach as long as a majoritarian definition of democracy is adopted as a basis of the examination: the individual complaint procedures established by international human rights treaties are not democratically legitimate; if we try to democratise them, we weaken the very protection of human rights that we wished to strengthen through these procedures. These conclusions are not surprising since a purely majoritarian definition of democracy is incompatible with the very idea of human rights, ${ }^{37}$ especially that of minority rights. ${ }^{38}$ In a majoritarian democracy, the legislature becomes omnipotent, while the judiciary (and NGOs) ${ }^{39}$ have a subordinate role.

Thus, the answer to the question whether individual complaint procedures are democratic or not depends entirely on the definition to be given to the term "democracy". Consequently, it is no

reelection bids in 1986. See Steven P Croley "The Majoritarian Difficulty" (1995) 62 U Chi L Rev 689, 737, n 144.

35 See a large number of impeachment or anti-retention campaigns listed on the page entitled "Judges under Fire" of the American Judicature Society's website www.ajs.org (accessed 31 October 2006).

36 "The English think they are free, they are sorely mistaken; they are only free when electing members of parliament; after that they are slaves" Jean-Jacques Rousseau Du contrat social (1762) Livre III, chapitre XV (Livre de poche, Paris, 1996) 118.

37 See Gerard Brennan "The Impact of a Bill of Rights on the Role of the Judiciary" in Philip Alston (ed) Promoting Human Rights Through Bills of Rights (Oxford University Press, Oxford, 1999) 456; Rebecca L Brown "Accountability, Liberty, and the Constitution" (1998) 98 Colum L Rev 531, 578.

38 Steven Wheatley "Deliberative Democracy and Minorities" (2003) 14 EJIL 507, 509.

39 See Minister for Foreign Affairs, Attorney-General and Minister for Immigration and Multicultural Affairs "Improving the Effectiveness of United Nations Committees" (29 August 2000) Joint News Release www.ag.gov.au (accessed 31 October 2006). 
surprise to see that most domestic lawyers who defend the democratic legitimacy of (national) judicial review look for a non-majoritarian definition of democracy: ${ }^{40}$

Any definition of democracy must include substantive values such as personal liberty and equality for minorities. Because majority rule is not favored over these substantive ends, judicial review should be evaluated, not in terms of its compatibility with majority rule, but in regard to whether it can further these substantive values. Judicial review may be antimajoritarian, but it is not a deviant institution. To the contrary, it is an excellent means for protecting precisely the values that democracy is designed to further.

Although one is theoretically free to formulate any definition of the term "democracy" to make it compatible with the idea of human rights, we should, if we wish to remain within the realm of positive law, first examine how the term "democracy" is employed in practice ${ }^{41}$ rather than simply stating that democracy and human rights are mutually interdependent in international law. ${ }^{42}$ In the following sections, we will first examine UN practice relating to the definition of "democracy" in general terms and then state practice concerning individual complaint procedures.

\section{A "Democracy" as Defined in UN Practice}

We will content ourselves with a succinct sketch of relevant UN documents, as a comprehensive examination of international practice would require a monograph. ${ }^{43}$ The most recent of the important UN documents referring to the notion of democracy is the 2005 World Summit Outcome, adopted by the UN General Assembly on 24 October 2005, which provides that: ${ }^{44}$

democracy is a universal value based on the freely expressed will of people to determine their own political, economic, social and cultural systems and their full participation in all aspects of their lives ... We stress that democracy, development and respect for all human rights and fundamental freedoms are interdependent and mutually reinforcing.

40 Erwin Chemerinsky "The Price of Asking the Wrong Question: An Essay on Constitutional Scholarship and Judicial Review" (1984) 62 Tex L Rev 1207, 1260 [footnote omitted]. See also Eugene V Rostow The Sovereign Prerogative (Yale University Press, New Haven, 1962) 149; Michael Mandel The Charter of Rights and the Legalization of Politics in Canada (Thompson Educational Pub, Toronto, 1994) 68-71.

41 Michel Troper Pour une théorie juridique de l'Etat (PUF, Paris, 1994) 346. See also Michael J Perry The Constitution, the Courts, and Human Rights (Yale University Press, New Haven, 1982) 3.

42 See, for example, James Crawford "Democracy and the Body of International Law" in Gregory H Fox and Brad R Roth (eds) Democratic Governance and International Law (Cambridge University Press, Cambridge, 2000) 92-93; Manfred Nowak Introduction to the International Human Rights Regime (Nijhoff, Leiden, 2003) $45-48$.

43 See Takanobu Kiriyama Minshushugi no Kokusaiho [International Law of Democracy] (Yuhikaku, Tokyo, 2001). For a survey of relevant international documents including non-UN ones, see Rafâa Ben Achour "Le droit international de la démocratie" (2000) 4 Cursos Euromediterráneos Bancaja de Derecho Internacional 325 .

44 UNGA Resolution 60/1 (24 October 2005) A/RES/60/1, para 135. 
This account of democracy faithfully follows the UN practice concerning the definition of democracy. ${ }^{45}$

At least two specific ideas underlie this UN definition of democracy. The first idea provides a negative definition of democracy: it is evident that democracy is not considered here as a simple majority rule. Because democracy and human rights are not only "mutually reinforcing" but also "interdependent", ${ }^{46}$ a majority decision to minimise minorities' rights will be held to be undemocratic. The UN practice thus clearly rejects the majoritarian definition of democracy. The second and more important is a positive idea of democracy: democracy requires people's full participation in all aspects of their lives.

In the four UN human rights treaties equipped with optional individual complaint procedures, only the ICCPR refers explicitly to the notion of democracy (in articles 14, 21 and 22). Unfortunately, the ICCPR provides no definition of democracy and the HRC's jurisprudence is not helpful in elucidating the notion appearing in these articles. ${ }^{47}$ However, the element of participation can be found in Article 25 of the ICCPR, which stipulates that "[e]very citizen shall have the right and the opportunity ... (a) to take part in the conduct of public affairs ...; (b) to vote and to be elected ...: (c) to have access ... to public service in his country." This element receives particular emphasis in the HRC's general comment on this article, which, according to the HRC, "lies at the core of democratic government". 48 In addition to the citizens' right to participate directly in the conduct of public affairs as members of legislative bodies or by holding executive office, ${ }^{49}$ the general comment mentions their participation "by exerting influence through public debate and dialogue with their representative through their capacity to organize themselves."

45 See Vienna Declaration and Programme of Action (25 June 1993) A/CONF.157/23, part I, para 8; Commission on Human Rights "Ways and means of overcoming obstacles to the establishment of a democratic society and requirements for the maintenance of democracy" (7 March 1995) E/CN.4/RES/1995/60, Preamble; see also a series of General Assembly resolutions entitled "Support by the United Nations system of the efforts of Governments to promote and consolidate new or restored democracies" (7 December 1994) A/RES/49/30; (20 December 1995) A/RES/50/133; (6 December 1996) A/RES/51/31; (21 November 1997) A/RES/52/18; (23 November 1998) A/RES/53/31; (29 November 1999) A/RES/54/36; (27 November 2000) A/RES/55/43; (14 December 2001) A/RES/56/96; (17 November 2003) $\mathrm{A} / \mathrm{RES} / 58 / 13$.

46 See also the resolution of the Commission on Human Rights on the "promotion of the right to democracy" (27 April 1999) E/CN.4/RES/1999/57, paras 1-3.

47 Frédéric Sudre Droit européen et international des droits de l'homme (7 ed, PUF, Paris, 2005) 214 ; Sarah Joseph, Jenny Schultz and Melissa Castan (eds) The International Covenant on Civil and Political Rights (2ed, Oxford University Press, Oxford, 2004) 422-426, 569-570, 576.

48 HRC General Comment No 25 (12 July 1996) CCPR/C/21/Rev.1/Add.7, para 1.

49 Ibid, para 6.

50 Ibid, para 8. 
The virtue of individual complaint procedures is, as its name indicates, in the possibility for individuals to participate in the procedure. Individuals who are not well represented in the domestic political process and not successful in domestic judicial procedure have a chance to be listened to in an international procedure. The individual complaint procedures provide the possibility for otherwise-unrepresented opinions to be heard and make it possible for individuals to participate better in wider aspects of their lives. ${ }^{51}$ They are thus able and expected to play a role in promoting and strengthening democracy.

Are we then allowed to conclude that "given the inseparability of democracy and human rights an international system of human rights protection cannot, by definition, but strengthen democracy in the States within the system"? ${ }^{52}$ This oft-advanced argument is logically flawed as it is based on a circular argument. Instead of being satisfied with such a circular argument, we need to pursue our investigation of the nature of democracy that the individual complaint procedures are supposed to promote.

\section{B Intensity of the Democratising Role of Individual Complaint Procedures}

In order to illuminate the nature of the democracy that the individual complaint procedures under the UN human rights treaties are supposed to promote, a comparison with the European Convention on Human Rights is useful. While the former is not judicial in the sense that outcomes are not binding decisions, judgments handed down by the latter are not only binding but becoming more and more effective. Does this difference in obligatory force and effectiveness have something to do with the nature of the democratic legitimacy of each system?

1 In the UN system: supervisory organs as proposal makers to sovereign states

In Toonen v Australia, the first communication from an Australian citizen under the first Optional Protocol of the ICCPR, the HRC found that certain Tasmanian laws which criminalised male homosexual acts between consenting adults in private constituted a violation of article 17, paragraph 1 of the $\mathrm{ICCPR}^{53}$ and declared that: "an effective remedy would be the repeal of [the relevant

51 For a similar discussion in the context of the democratic legitimacy of the judiciary in the internal legal order, see Martin Shapiro "Judicial Modesty, Political Reality, and Preferred Position" (1962) 47 Cornell L Q 175, 196-197; Dominique Rousseau Droit du contentieux constitutionnel (5 ed, Montchrestien, Paris, 1999) $449-450$.

52 C P Economides "The Right of Individual Petition: Means of Strengthening Democracy" in Democracy and Human Rights: Proceedings of the Colloquy organised by the Government of Greece and the Council of Europe in co-operation with the Centre of International and European Economic Law of Thessaloniki (Engel, Kehl am Rhein, 1990) 67.

53 Toonen v Australia Communication No 488/1992 (4 April 1994) CCPR/C/50/D/488/1992, para 9. 
provisions] of the Tasmanian Criminal Code."54 Australia responded to the HRC by adopting a Human Rights (Sexual Conduct) Act in 1994 to override the Tasmanian laws in question. ${ }^{55}$

The Australian Government found no problem of democratic deficit in this process. Michael Lavarch, the Attorney-General, explaining the draft Human Rights (Sexual Conduct) Act in the Australia's House of Representatives, stated as follows: ${ }^{56}$

It has been claimed that Australia is being dictated to by foreign law-making bodies and that our national sovereignty has been diminished ... First of all, the bill does not represent the outcome of some process of abdication of national sovereignty. On the contrary, the fact that our national parliament is now debating this bill itself puts lie to that claim ... It has been argued that the ability of Australian citizens to take a complaint to the Human Rights Committee is a transfer of judicial power to a foreign body ... Such an argument is totally flawed ... The Human Rights Committee is not a court. It does not make binding decisions. It has no power of enforcement. Its decisions do not oblige any action from Australia to change our laws or alter our practices.

In fact, the Australian Government consistently maintains that the HRC's views are not binding. In $A v$ Australia ${ }^{57}$ the Committee found that A, a Cambodian asylum seeker, had been subjected to arbitrary detention contrary to Article 9 of the ICCPR because of the length of his detention. ${ }^{58}$ The Australian Government stated that it could not accept the Committee's view which advanced, according to the Government, an incorrect interpretation of Article 9. ${ }^{59}$ It also declared in several other cases not to accept the HRC's findings. ${ }^{60}$

54 Ibid, para 10

55 UN Human Rights Committee "Report of the Human Rights Committee" (13 April 1997) A/51/40 vol I, para 456. For the difficult relationship between the Commonwealth and Tasmanian governments on this issue, see Wayne Morgan "Sexuality and Human Rights" (1992) 14 Australian YBIL 277, 291-292; Brian R Opeskin and Donald R Rothwell "The Impact of Treaties on Australian Federalism" (1995) 27 Case W Res J Int'l L 1, 51-54.

56 Michael Lavarch (Attorney-General) House of Representatives Debates (12 October 1994) 1775 reprinted in "Australian Practice in International Law" (1995) 16 Australian YBIL 473-474. See also John Kidd "Can International Law Protect our Civil Rights?" (1994-1995) 18 UQLJ 305, 313.

57 See Sam Blay and Ryszard Piotrowicz "The Awfulness of Lawfulness" (2000) 21 Australian YBIL 1.

58 A v Australia Communication No 560/1993 (30 April 1997) CCPR/C/59/D/560/1993.

59 "Australian Practice in International Law 1997" (1998) 19 Australian YBIL 208-209. For the HRC's response, see "Report of the Human Rights Committee" (2000) A/55/40 vol I, paras 520-521; "HRC 2005 Report", above n 1, vol I, 121.

60 "HRC 2005 Report", above n 1, vol II, 493 (Young v Australia Communication No 941/2000 (18 September 2003) $\mathrm{CCPR} / \mathrm{C} / 78 / \mathrm{D} / 941 / 2000$, violation of Article 26 committed by discrimination on grounds of sexual orientation in provision of social security benefits); ibid, 494 (Baban v Australia Communication No 1014/2001 (18 September 2003) CCPR/C/78/D/1014/2001, a case similar to $A v$ Australia); ibid, 495 (Bakhtiyari v Australia Communication No 1069/2002 (6 November 2003) CCPR/C/79/D/1069/2002, 
Canada adopts a similar approach. It often amends relevant provisions of its laws in order to comply with the views expressed by the HRC which it accepts: in response to the HRC's view in Lovelace $v$ Canada, ${ }^{61}$ which had recognised Canada's violation of Article 27 (rights of persons belonging to minorities) due to its denial of the author's right to live on the reserve, Canada amended the Indian Act to comply with the HRC's findings; ${ }^{62}$ Canada (precisely, Quebec) also decided to amend its relevant legislation so as to comply with the HRC's views in Ballantyne $v$ Canada, ${ }^{63}$ which had acknowledged that the French-only provisions concerning commercial signs and firm names contravened Article 19 (freedom of expression). ${ }^{64}$ However, it emphasises the non-binding character of the views ${ }^{65}$ and refuses to accept the ones which it considers incorrect. ${ }^{66}$ New Zealand, for its part, took measures "to give effect to the Committee's Views"67 concerning Rameka et al $v$ New Zealand, ${ }^{68}$ which is the first case where the HRC found New Zealand in violation of the ICCPR in the individual complaint procedure. ${ }^{69}$

another case similar to $A v$ Australia). See generally Ann Kent "The Unpredictability of Liberal States" (2002) 6 Int'l J HumRts 55; Rochelle L Haller "Australia's Cold-Shoulder" (2002) 17 N Y L Sch J Hum Rts 937

61 Lovelace v Canada Communication No 24/1977 (30 July 1981) CCPR/C/13/D/24/1977.

62 "Response, Dated 6 June 1983, of the Government of Canada to the Committee's views" in "Selected Decisions of the Human Rights Committee under the Optional Protocol" (vol 2, 1990) CCPR/C/OP/2, 224-225; see also Camille Jones "Towards Equal Rights and Amendment of Section 12(1)(b) of the Indian Act" (1985) 8 Harv Women's L J 195, 209.

63 Ballantyne v Canada Communication No 359/1989 (5 May 1993) CCPR/C/47/D/359/1989.

64 "HRC 2005 Report", above n 1, vol I, 123; see also William Green "Language Regimes, Minority Language Rights, and International Legal Issues" (1999) 26 Syracuse J Int'l L \& Com 267, 281-282.

65 Ahani v R (Attorney General of Canada) 208 DLR (4th) 66, para 25 (Ontario CA). See also Joanna Harrington "Punting Terrorists, Assassins and Other Undesirables" (2003) 48 McGill LJ 58-61, 82-86.

66 See Canada's response to the HRC's views in Ahani v Canada Communication No 1051/2002 (15 June 2004) $\mathrm{CCPR} / \mathrm{C} / 80 / \mathrm{D} / 1051 / 2002$, concerning removal to a country where the author risks torture and/or execution, "HRC 2005 Report", above n 1, vol II, 499-501; "Canada's Responses to the List of Issues, Presentation of the Fourth and Fifth Reports, Committee against Torture" (May 2005) 8-9 (Question 5) www.pch.gc.ca (accessed 28 May 2006). See also "Report of the Committee against Torture" (2005) A/60/44, 70-72 (Canada's follow-up information on the CAT's decision in Falcon Rios v Canada Communication No 133/1999 (17 December 2004) CAT/C/33/D/133/1999).

67 "Response to the views of the Human Rights Committee under the optional protocol to the International Covenant on Civil and Political Rights by Messrs Rameka, Harris and Tarawa - Communications No 1090/2002" (3 February 2004) www.justice.govt.nz (accessed 31 October 2006).

68 Communication No 1090/2002 (15 December 2003) CCPR/C/79/D/1090/2002 (concerning the inability of a detainee to challenge the existence of substantive justification of his continued detention for preventive reasons is in violation of his right under article 9, paragraph 4).

69 "HRC 2005 Report", above n 1, vol I, 130. 
Even though the HRC's views are not legally binding, ${ }^{70}$ States Parties are expected to bring their conduct into line with them. ${ }^{71}$ In fact, States Parties, when they do not accept the HRC's views, usually try to explain why they do not and to justify their own interpretation of relevant provisions of the ICCPR, as Australia and Canada did in the cases just mentioned. The HRC's views thus provoke public debates and may exert influence over the decision-making of the government in question, even when it does not accept these views. Ivan Shearer, current member of the ICCPR, states that: ${ }^{72}$

The stand-off in relation to this case $[A v$ Australia $]$ is most regrettable [...] The most positive thing that may be said is that, in a climate of free speech and the Australian tradition of robust public debate, the government is constantly under pressure to justify its policies and actions. The Committee's views, rather than being ignored, are constantly being reinforced in the course of this debate.

The HRC's views thus introduce unheard voices into the internal political process and urge the "defendant" state to reconsider its domestic laws and policies.

It is, however, up to the executive and the parliament of the State party concerned whether to amend internal legislation or alter administrative practice, as the HRC's views are not legally binding. Therefore, it would be an overstatement to qualify the individual complaint procedures established by UN-related human rights treaties as elements of "transnational", "universal", "global" or "cosmopolitan" democracy; ${ }^{73}$ they instead contribute to enhancing democracy within the framework of sovereign states. It should be kept in mind that the abovementioned 2005 World Summit Outcome and other UN documents on democracy continuously refer to "the people", of which the right of self-determination is stipulated in Article 1 of the ICCPR. Accordingly, the democratic legitimacy of the individual complaint procedures established by the UN human rights treaties is founded, ultimately, on that of States Parties, ${ }^{74}$ as the Australian Attorney-General correctly stated in relation to the Toonen case.

70 See Scott Davidson "Procedure under the Optional Protocol" in Alex Conte, Scott Davidson and Richard Burchill (eds) Defining Civil and Political Rights (Ashgate, Aldershot, 2004) 17, 28.

71 For the so-called "follow-up" mechanisms established by UN human rights bodies, see Markus G Schmidt "Follow-Up Mechanisms before UN Human Rights Treaty Bodies and the UN Mechanisms Beyond" in Anne F Bayefsky (ed) The UN Human Rights Treaty System in the 21st Century (Kluwer, The Hague, 2000) 233; Nisuke Ando "The Follow-Up Procedure of the Human Rights Committee's Views" in Liber amicorum Judge Shigeru Oda (vol 1, Kluwer, The Hague, 2002) 1437.

72 Ivan Shearer "The Domestic Application of the Covenant in Australia" in Nisuke Ando (ed) Towards Implementing Universal Human Rights (Nijhoff, Leiden, 2004) 261.

73 See generally David Held Democracy and the Global Order (Polity, Cambridge, 1995).

74 See Louis Favoreu's penetrating observation on the democratic legitimacy of internal courts, which is founded, according to him, on "le constituant". Louis Favoreu "La légitimité du juge constitutionnel" (1994) Revue internationale de droit comparé 557, 578. 
2 In the European system: the European Court of Human Rights as a court of the European legal order

The European Convention on Human Rights presents a totally different picture. One fundamentally important distinction is that the judgments of the European Court of Human Rights are legally binding. ${ }^{75}$ Even more important, however, is the continuously deepening intrusion of the Court's judgments into the internal legal orders of the states parties.

Traditionally, the European Court leaves the respondent state to decide upon the measures needed to implement the judgment in its internal legal order. ${ }^{76}$ This clear separation between internal and international (or European) legal orders is, however, becoming blurred. By legislation or through jurisprudence, it has become possible in more than twenty European states ${ }^{77}$ for national courts to rehear cases on which final judicial decisions have already been handed down, if the European Court of Human Rights later finds a violation of the European Convention on Human Rights in relation to the case in question. ${ }^{78}$

For example, Article 626-1 of the French Code de procédure pénale stipulates: ${ }^{79}$

Le réexamen d'une décision pénale définitive peut être demandé au bénéfice de toute personne reconnue coupable d'une infraction lorsqu'il résulte d'un arrêt rendu par la Cour européenne des droits de l'homme que la condamnation a été prononcée en violation des dispositions de la convention de sauvegarde des droits de l'homme et des libertés fondamentales ou de ses protocoles additionnels, dès lors que, par sa nature et sa gravité, la violation constatée entraîne pour le condamné des conséquences dommageables auxquelles la «satisfaction équitable» allouée sur le fondement de l'article 41 de la convention ne pourrait mettre un terme.

This is a huge step. In order to bring a case before the European Court of Human Rights, the plaintiff has to exhaust local remedies. ${ }^{80}$ In most cases, he or she has to obtain a final judgment of the

75 European Convention on Human Rights, above n 14, art 46, para 1.

76 Marckx v Belgium (1979) 31 ECHR Ser A, para 58; Soering v United Kingdom (1989) 161 ECHR Ser A, para 125.

77 Elisabeth Lambert-Abdelgawad "La réexamen de certaines affaires suite à des arrêts de la Cour européenne des droits de l'homme" (2001) Revue trimestrielle des droits de l'homme 715, 728-729.

78 See Committee of Ministers "Recommendation No R (2000) 2" (19 January 2000) www.coe.int (accessed 31 October 2006).

79 Inséré par Loi n ${ }^{\circ}$ 2000-516 du 15 juin 2000 art 89, JO du 16 juin 2000 www.legifrance.gouv.fr (last accessed 31 October 2006). In translation "The reconsideration of a final criminal decision may be requested for the benefit of any person judged guilty of an offence, where this conviction is held, in a judgment given by the European Court of Human Rights, to have been declared in violation of the provisions of the Convention for the Protection of Human Rights and Fundamental Freedoms, or its additional Protocols, and where the declared violation, by its nature or seriousness, has led to harmful repercussions for the convicted person, which the "just satisfaction" granted under article 41 of the Convention cannot bring to an end." 
supreme court, which would declare that there is no violation of the European Convention on Human Rights. When the European Court nevertheless finds a violation, internal courts and tribunals of the defendant state have to reopen the case and have no choice but to follow the interpretation given by the European Court of Human Rights in the rehearing procedure, ${ }^{81}$ which may lead to a complete reversal of the final judgment rendered by the supreme court. ${ }^{82}$ The introduction of this radical system led commentators to observe "a progressive transformation of the Court of Strasbourg into a court of the fourth instance", ${ }^{83}$ which "deprives the Cour de cassation of the status of the supreme court." 84

All the more astonishing is that the French parliament adopted this legislation swiftly without much debate. No one in the Assemblée nationale or in the Sénat complained of a democratic deficit of the European Court of Human Rights or of a loss of French sovereignty. ${ }^{85}$ The legislation was not brought by anybody before the Conseil constitutionnel for a review of constitutionality. ${ }^{86}$ It seems that there was a large consensus among parliamentary members, the executive, professional lawyers as well as academics that the French system needs to be "Europeanised." In contrast to the Australian Attorney-General, who emphasised the "free will" of the parliament whether or not to comply with the HRC's views, the French Minister of Justice reiterated the necessity for France to get in line with the European standards. ${ }^{87}$ This consensus is, it is submitted, based on the growing recognition of the

80 European Convention on Human Rights, above n 14, art 35, para 1.

81 Fabienne Rinaldi "Des demandes en révision et en réexamen d'une décision pénale définitive" (12 juillet 2001) Petites affiches $\mathrm{N}^{\mathrm{o}} 138,4,9$.

82 See Article 626-4 of the French Code de procédure pénale. An example of the reversal is found in the famous Maurice Papon trial: C assises Gironde (10 October 1997) (1998) Dalloz, jur 173, note Roujou de Boubée et Somm. 169, obs J Pradel; C cass (21 October 1999) (2000) Dalloz, jur 602, note Anne Teissier; Papon v France (25 July 2002) 54210/00 (http://www.ehcr.coe.int> (last accessed 31 October 2006); (2002) Dalloz, Somm 2572, obs J-F Renucci; (2002) Gazette du Palais, jur 1489, note Christophe Pettiti; C cass (Ass plén) (11 juin 2004) (2005) Gazzete du Palais, jur 456, note Yves Monnet.

83 Régis de Gouttes "La procédure de réexamen des décisions pénales après un arrêt de condamnation de la Cour européenne des droits de l'homme" in Libertés, justice, tolérance: Mélanges en hommage au Doyen Gérard Cohen-Jonathan (Bruylant, Bruxelles, 2004) 563.

84 Marie-Hélène Renaut "Révision et réexamen: les condamnations pénales sont de moins en moins définitives" Petites affiches (18 March 2003) $\mathrm{N}^{0}$ 55, 6, 20.

85 Assemblée nationale, $2^{\mathrm{e}}$ séance du 10 février 2000, JOAN (CR) 1009; Sénat, séance du 4 avril 2000, JOS (CR), 1838-1839; Assemblée nationale, séance du 24 mai 2000, JOAN (CR) 4664-4665 ; Sénat, séance du 30 mai 2000, JOS (CR) 3380-3382. See also Sénat, Rapport de M Charles Jolibois, au nom de la commission des lois, (22 March 2000) No 283, 114-116, 258 ; Assemblée nationale et Sénat, Rapport de Mme Christine Lazerges et de M Charles Jolibois, au nom de la commission mixte paritaire (18 mai 2000) $\mathrm{N}^{\circ} 2409$ (Assemblée nationale), Nº 349 (Sénat), 140-142.

86 French Constitution, art 61, alinéa 2 www.conseil-constitutionnel.fr (accessed 29 May 2006).

87 See Madame Elisabeth Guigou, garde des sceaux, Sénat, séance du 30 mai 2000, JOS (CR) 3382. 
European Convention on Human Rights "as a constitutional instrument of European public order (ordre public)", ${ }^{88}$ which presupposes a Europe-wide democracy.

\section{CONCLUSION}

The question as to why "a body that is not elected or otherwise politically responsible in any significant way is telling the people's elected representatives that they cannot govern as they'd like"89 has long been debated by domestic lawyers. Although the powerlessness of individual complaint procedures established by human rights treaties allowed international lawyers to feign ignorance of the problem, the increasing development of these procedures urges us to come to grips with it. It is to be noted in this context that democratic theory used to be considered irrelevant to the European Communities: only when the European people realised that the EC's activities really affected their lives did they began to think about the democratic deficit of the EC. ${ }^{90}$

While the human rights treaty bodies may found their legitimacy on their expertise, the undemocratic nature of the norms that they apply and their undemocratic mode of election make it impossible to consider them as democratic themselves. However, a democratisation of the treaty bodies may result in a lesser protection of human rights and cast a doubt upon their raison-d'être.

Taken as a whole, the system in which individual complaint procedures function may be categorised as democratic. Indeed, democracy is considered in UN practice as interdependent with human rights and as based on people's full participation in their lives. Individual complaint procedures, protecting human rights and enhancing people's participation in political decision-making processes, may play a role in favour of democracy.

The individual complaint procedures in the UN system are established by "international" human rights treaties, but the democracy that they are supposed to promote is not necessarily international. Democratically elected governments are not ready to submit themselves to the legally-binding control assumed by a human rights supervisory organ in an individual complaint procedure. They accept being subjected to international legal norms on human rights but are not willing to renounce their power of interpretation. If democracy is about demos kratos, the demos remains captured within the framework of sovereign states on the international plane and the kratos must thus come from within these sovereign states: democratically elected governments cannot accept any external authority, which is by definition not democratic. The supervisory organs established by international human

88 Loizidou v Turkey, Preliminary Objections (23 March 1995) 310 ECHR Ser A, 27, para 75. For the notion of "European public order", see generally Caroline Picheral L'ordre public européen (La documentation française, Paris, 2001).

89 John Hart Ely Democracy and Distrust (Harvard University Press, Cambridge, 1980) 4-5.

90 Yves Mény attributes the term "democratic deficit" to David Marquand's Parliament for Europe published in 1979 (Jonathan Cape, London). Yves Mény "De la démocratie en Europe" (2003) 41 Journal of Common Market Studies 1, 1. 
rights treaties may play an important role as the makers of proposals to democratically elected governments, but it is the latter that has the final say.

This does not mean that the demos remains captured within the sovereign states forever. Europe is now in the process (admittedly a long and slow one) of developing a Europe-wide demos. Democratically elected governments have begun to relinquish their powers to European institutions. The transfer of power by democratic governments to external institutions is possible only when the governments recognise the external institutions as no less democratic, unless they renounce the democratic theory itself. Thus, the democratic legitimacy of individual complaint procedures matters. As long as they lack democratic legitimacy, democratically elected governments will not accept any extension of the legal powers of supervisory organs. Through this analysis the intrusiveness of the European Court of Human Rights and the modesty of the UN human rights bodies can be democratically explained. 